\title{
Metaevaluation of National Weatherization Assistance Program Based on State Studies, 1993-2002
}

\author{
Linda Berry
}

Martin Schweitzer 

ORNL/CON-488

\title{
Metaevaluation of National Weatherization Assistance Program Based on State Studies, 1993-2002
}

\author{
Linda Berry \\ Martin Schweitzer
}

February 2003

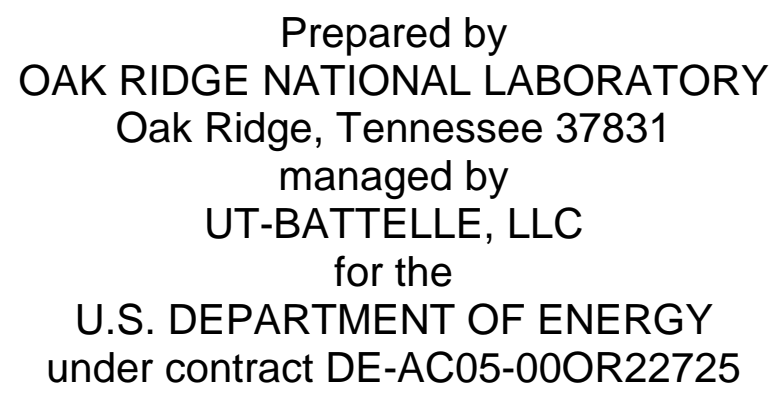





\section{TABLE OF CONTENTS}

$\underline{\text { Page }}$

LIST OF FIGURES

LIST OF TABLES . $\mathrm{V}$

EXECUTIVE SUMMARY $\ldots \ldots \ldots \ldots \ldots \ldots \ldots \ldots \ldots \ldots \ldots \ldots \ldots \ldots$ vii

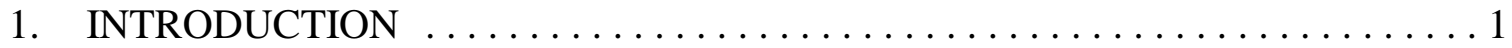

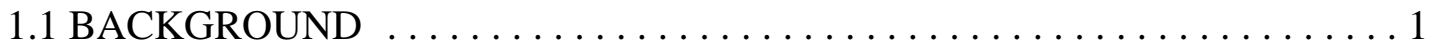

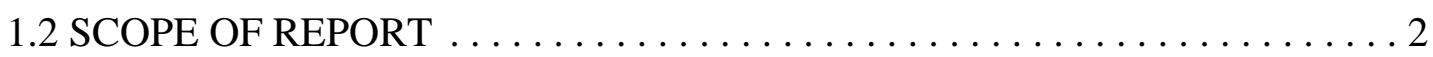

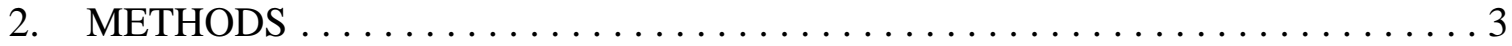

2.1 LOCATING RECENT STATE-LEVEL EVALUATIONS . . . . . . . 3

2.2 SELECTING THE SET OF STATE-LEVEL EVALUATIONS TO

INCLUDE IN THE ANALYSIS OF NATURAL GAS SAVINGS . . . . . . . 3

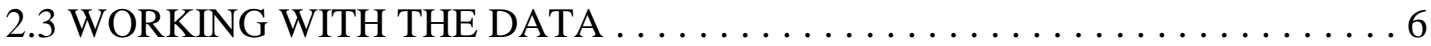

2.4 SAMPLE SIZES AND METHODS OF STATE STUDIES $\ldots \ldots \ldots \ldots \ldots \ldots$

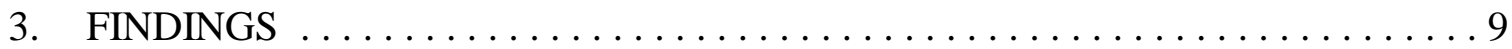

3.1 NATURAL GAS SAVINGS FROM STATE STUDIES . . . . . . . . . . 9

3.2 ESTIMATE OF NATIONAL NATURAL GAS SAVINGS $\ldots \ldots \ldots \ldots \ldots$

3.3 COST EFFECTIVENESS RESULTS FOR BUILDINGS

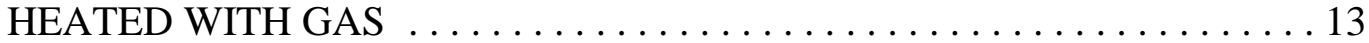

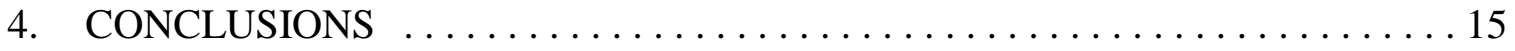

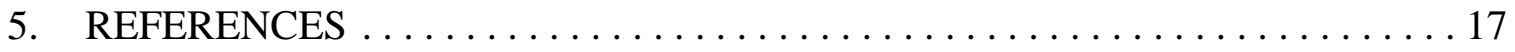

APPENDIX A: OTHER FUELS STUDY RESULTS $\ldots \ldots \ldots \ldots \ldots \ldots \ldots \ldots$ A-1

APPENDIX B: ELECTRICALLY-HEATED HOUSES $\ldots \ldots \ldots \ldots \ldots \ldots \ldots \ldots$ B-1

APPENDIX C: SAVINGS IN HOUSES USING ELECTRICITY ONLY FOR

NONHEATING PURPOSES $\ldots \ldots \ldots \ldots \ldots \ldots \ldots \ldots \ldots \ldots \ldots$

APPENDIX D: EVALUATION METHOD USED IN IOWA STUDIES $\ldots \ldots \ldots$ D-1 



\section{LIST OF FIGURES}

Figure 1 States with studies used in the third metaevaluation $\ldots \ldots \ldots \ldots \ldots \ldots \ldots$

Figure 2 Comparison of whole house natural gas savings from three data sets: means and $90 \%$ confidence intervals $\ldots \ldots \ldots \ldots \ldots \ldots$

Figure 3 Plot of energy savings by pre-weatherization consumption for gas-heated structures $\ldots \ldots \ldots \ldots \ldots \ldots \ldots$

Figure 4 Average percentage whole-house savings of natural gas:

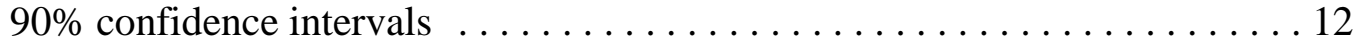

\section{LIST OF TABLES}

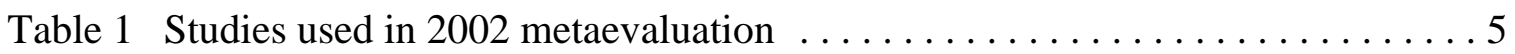

Table 2 Estimate of average national savings using pre-weatherization

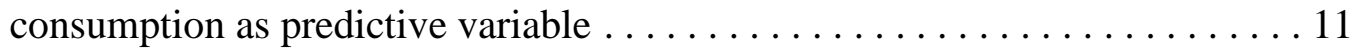

Table 3 Estimated national savings for a typical gas-heated

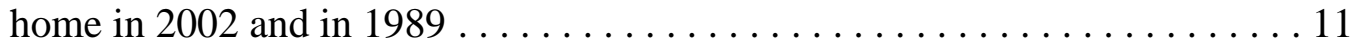





\section{EXECUTIVE SUMMARY}

\section{ES.1 INTRODUCTION}

The National Weatherization Assistance Program, sponsored by the U.S. Department of Energy (DOE) and implemented by state and local agencies throughout the United States, weatherizes homes for low-income residents in order to increase their energy efficiency and lower utility bills. Research staff members at Oak Ridge National Laboratory (ORNL) have performed two previous metaevaluations of this program (Berry, 1997; Schweitzer and Berry, 1999). Both of these earlier metaevaluations involved synthesizing the results from individual studies of state weatherization efforts completed during a several year period. This report is the third in a series of metaevaluations of state-level studies. It is built on the foundation developed by the previous two metaevaluations.

The purpose of this report, like that of the two earlier ORNL metaevaluations, is to provide a current estimate of the average national energy savings per home weatherized for the Weatherization Assistance Program based on the relevant state-level studies. All three of the metaevaluations, including this one, were designed to be updates to the findings of a national evaluation of the Weatherization Assistance Program, which examined a representative national sample of several thousand structures weatherized in 1989 (Brown, Berry, Balzer, and Faby 1993).

Although the first and second metaevaluations used separate sets of state-level studies, completed during different time periods, there was little difference in their findings about the typical national energy savings per weatherized home for homes that heat with natural gas. Our initial analysis efforts for this report involved repeating the same procedures that had been used in the previous two reports. In particular, we collected and examined only the state-level evaluations that had become available between September of 1998 and August of 2002. Once again, we found little difference in the average energy savings estimates per weatherized home that were produced with this third set of the most recently available state-level evaluations.

In order to increase our sample size, our ability to cover all of the major climate regions of the United States, and the statistical rigor of our results, we decided to include findings from all of the post-1992 state-level evaluations in the current metaevaluation. ORNL has collected and reviewed 37 state-level evaluations during the past six years. All of the relevant studies are included in the analysis discussed in this report. The number of the information request to the State Weatherization offices (1st, 2nd, or 3rd) that first located each state-level evaluation is shown in Table ES-1. 
Table ES-1. Studies used in 2002 metaevaluation

\begin{tabular}{|c|c|c|c|c|}
\hline \multirow[b]{2}{*}{ State } & \multirow[b]{2}{*}{$\begin{array}{c}\text { Information } \\
\text { request to states }\end{array}$} & \multicolumn{3}{|c|}{ Fuel studied* } \\
\hline & & Natural gas & $\begin{array}{c}\text { Electricity } \\
\text { (space-heating) }\end{array}$ & $\begin{array}{c}\text { Electricity } \\
\text { (baseload/no } \\
\text { space heating) }\end{array}$ \\
\hline Colorado & $1 \mathrm{st}$ & $\mathrm{X}$ & & \\
\hline Colorado & 2nd & $X$ & & \\
\hline Colorado & $3 \mathrm{rd}$ & $\mathrm{X}$ & & \\
\hline Delaware & 2nd & & $X$ & \\
\hline District of Columbia & 2nd & $\mathrm{X}$ & $\mathrm{X}$ & \\
\hline Georgia & $3 \mathrm{rd}$ & $X$ & & \\
\hline Indiana & 1 st & $X$ & & \\
\hline Indiana & $2 \mathrm{nd}$ & $\mathrm{X}$ & & \\
\hline Iowa & $1 \mathrm{st}$ & $\mathrm{X}$ & & \\
\hline Iowa & 2nd & $X$ & & \\
\hline Iowa & 2nd & $X$ & & $X$ \\
\hline Iowa & $3 \mathrm{rd}$ & $X$ & & $X$ \\
\hline Kansas & $1 \mathrm{st}$ & $X$ & & \\
\hline Minnesota & $1 \mathrm{st}$ & $X$ & & \\
\hline Minnesota & $2 \mathrm{nd}$ & $\mathrm{X}$ & & \\
\hline Nebraska & 1 st & $\mathrm{X}$ & & \\
\hline New York & 1 st & $\mathrm{X}$ & & \\
\hline North Carolina & $1 \mathrm{st}$ & $X$ & & \\
\hline Ohio & 1 st & $\mathrm{X}$ & & \\
\hline Ohio & 2nd & $X$ & $X$ & \\
\hline Texas & $3 r d$ & $\mathrm{X}$ & $\mathrm{X}$ & \\
\hline Texas & $3 \mathrm{rd}$ & $X$ & & \\
\hline Vermont & 1 st & $\mathrm{X}$ & & \\
\hline Vermont & 2nd & $X$ & & $\mathrm{X}$ \\
\hline Vermont & $3 \mathrm{rd}$ & $\mathrm{X}$ & & $\mathrm{X}$ \\
\hline Washington & $3 \mathrm{rd}$ & $X$ & $\mathrm{X}$ & \\
\hline West Virginia & $3 \mathrm{rd}$ & & $X$ & \\
\hline Wisconsin & 1 st & $\mathrm{X}$ & & \\
\hline Wyoming & $3 r d$ & $X$ & & \\
\hline Wyoming & $3 \mathrm{rd}$ & $X$ & & \\
\hline
\end{tabular}


In June and July of 2002, weatherization personnel in each state office were contacted to determine which states had completed evaluations of their programs since the time of ORNL's second survey of the states in 1998. The key data required from the post-1998 evaluations we located were obtained by reading the new state reports, documenting study findings, and by follow-up contacts with state-level evaluators, if needed. As a result of this year's efforts, as well as those of previous years, we now have usable information from 37 post-1992 state-level weatherization program evaluations conducted by 16 states. Twenty-eight of these state-level studies examined houses that used natural gas for heating, six reported savings for houses with electric heat, four looked at the use of electricity for baseload (no electric heat) purposes, and one (which is discussed in Appendix A) focused on savings in Minnesota homes that heat with propane and fuel oil. Separate analyses were performed for each fuel source and application. The results of the natural gas analysis, which used data from the 28 post-1992 state studies of gas-heated houses, are discussed in the main body of this report. Findings on electrically heated homes, which are based on the data from the six state-level studies of electrically heated dwellings, are presented in Appendix B. Findings on electric baseload savings in the nonheating electric end uses that the Program addresses, such as high efficiency lighting replacements, are presented in Appendix C.

The data analyses performed for this metaevaluation had two objectives: (1) to quantify the savings by fuel type experienced by weatherized households in the states that provided information for the fuel type under consideration; and (2) to estimate the average household savings that could be expected nationwide for natural gas using the regression model parameters obtained from the complete set of 28 state-level studies on homes that heat with natural gas.

From the previous two metaevaluations, we knew that the best predictor of expected energy savings is the level of pre-weatherization consumption. Using only this predictor it was possible to explain $67.1 \%$ of the variation in the dependent variable of natural gas energy savings in the 28 state-level evaluations. A regression model was developed only for gas-heated homes, because this was the only fuel for which there were enough state studies to allow a reasonably accurate analysis. Using the results of a regression model, we estimated the typical amount of natural gas per dwelling that would be expected to be saved nationwide. This was accomplished by applying the parameters of the regression equation of the predictive model to the average national value for the independent variable of pre-weatherization consumption. 


\section{ES.2 KEY FINDINGS}

Mean values for pre-weatherization energy consumption and for weatherization-induced energy savings, as reported in the 28 state studies of gas-heated residences, were used as inputs for the development of a simple linear regression model. The results of the regression analysis revealed a strong positive relationship between pre-weatherization energy consumption and weatherization-induced energy savings ( $\mathrm{R}$-Square $=0.671 ; \mathrm{p}=0.0001)$. This means that, consistent with the findings from many previous studies, households with higher pre-weatherization energy use will typically save more energy when they are weatherized. The R-Square of 0.671 means that $67.1 \%$ of the variance in energy savings is explained by pre-weatherization levels of natural gas consumption.

The descriptive equation produced by the simple regression analysis mentioned above has an intercept value of -11.29 and a slope value of 0.3035 . The average pre-weatherization consumption of natural gas in Program homes that heat with natural gas is 133 million BTUs per year (Brown, Berry, Balzer, and Faby 1993). Using these parameters and inputs, the estimate of average household savings is 29.1 million BTUs annually. This represents $21.9 \%$ of the average pre-weatherization consumption of natural gas for all end uses and $30.8 \%$ of pre-weatherization space heating consumption.

For electrically-heated houses, savings averaged $10.5 \%$ of pre-weatherization whole-house electric use and $26.7 \%$ of pre-weatherization space heating electric consumption. This indicates that the Weatherization Assistance Program achieves approximately the same results in both gas- and electrically-heated dwellings in terms of reducing the amount of energy used for space heating.

With average savings of 29.1 million BTUs annually, a benefit/cost ratio was calculated for the weatherization program nationwide. Two different perspectives were used: the program perspective, which compares the discounted value of energy savings to total program costs; and the societal perspective, which compares the discounted value of both energy and non-energy benefits to total program costs. The benefit/cost ratio for the program perspective was 1.30 (assuming a discount rate of $3.2 \%$ and the fuel price forecasts shown on the Energy Information Administration's website in September of 2002). The benefit/cost ratio for the societal perspective was 2.70 , with the same discount rate and price forecasts.

The average national savings per gas-heated household in 2002 can be compared to the findings from the first two metaevaluations and the national evaluation of the 1989 weatherization program. As shown in Table ES-2, average savings per gas-heated household as a percent of pre-weatherization consumption for all end uses averaged $21.9 \%$ with the estimation methods used in this report, $19.6 \%$ on the second metaevaluation, $23.4 \%$ in the first metaevaluation, and $13.0 \%$ in the 1989 national evaluation. Although most of the state-level evaluations did not measure the portion of 
total pre-weatherization consumption used for space heating, this was assumed to be $71 \%$ to allow comparison with previous studies. With this assumption, natural gas savings as a percent of the assumed amount of pre-weatherization consumption for space heating averaged $30.8 \%$ in the years covered here, $27.6 \%$ in the second metaevaluation, $33.5 \%$ on the first metaevaluation, and $18.3 \%$ in 1989.

A look at the $90 \%$ confidence intervals presented in Table ES-2 indicates that there is a significant difference between the average savings estimated by this metaevaluation and those reported in the 1989 national evaluation. The implication of these findings is that weatherization-induced savings have, in fact, increased markedly since 1989. In contrast, there is very substantial overlap in the $90 \%$ confidence intervals for all three metaevaluations, indicating that there is little difference among their findings.

\section{Table ES-2. Estimated national savings for a typical gas-heated home in 2002 and in 1989}

\begin{tabular}{|c|c|c|c|}
\hline & $\begin{array}{l}\text { Average household } \\
\text { natural gas savings, } \\
\text { in MBTU }\end{array}$ & $\begin{array}{l}\text { Average household } \\
\text { natural gas savings as } \\
\text { a percent of pre- } \\
\text { weatherization } \\
\text { consumption for all }^{\text {end uses }}{ }^{a} \\
\end{array}$ & $\begin{array}{l}\text { Average household } \\
\text { natural gas savings as } \\
\text { a percent of pre- } \\
\text { weatherization } \\
\text { consumption for } \\
\text { space-heating } \\
\end{array}$ \\
\hline $\begin{array}{l}\text { Current ORNL } \\
\text { metaevaluation }\end{array}$ & $\begin{array}{c}29.1 \\
(25.6-31.6)\end{array}$ & $\begin{array}{c}21.9 \\
(19.9-23.8)\end{array}$ & $\begin{array}{c}30.8 \\
(28.1-33.5)\end{array}$ \\
\hline $\begin{array}{l}\text { Second } \\
\text { metaevaluation }\end{array}$ & $\begin{array}{c}26.1 \\
(19.4-32.8)\end{array}$ & $\begin{array}{c}19.6 \\
(14.6-24.6)\end{array}$ & $\begin{array}{c}27.6 \\
(20.5-34.7)\end{array}$ \\
\hline First metaevaluation & $\begin{array}{c}31.2 \\
(22.9-38.6)\end{array}$ & $\begin{array}{c}23.4 \\
(17.2-29.0)\end{array}$ & $\begin{array}{c}33.5 \\
(24.6-41.4)\end{array}$ \\
\hline $\begin{array}{l}1989 \text { national } \\
\text { evaluation }\end{array}$ & $\begin{array}{c}17.3 \\
(15.1-19.5)\end{array}$ & $\begin{array}{c}13.0 \\
(11.3-14.7)\end{array}$ & $\begin{array}{c}18.3 \\
(16.0-20.6)\end{array}$ \\
\hline
\end{tabular}

${ }^{a}$ Followed by $90 \%$ confidence interval

There are several possible reasons why average weatherization-induced energy savings per household that heats with natural gas increased between 1989, the year studied in the national weatherization evaluation, and the mid- to late 1990's. Advanced audits became widely used during the 1990's and the use of blower-doors as a diagnostic tool became commonplace. There have been no equally dramatic changes in the structure or practices of the Weatherization Assistance Program that address heating energy use in the past few years, which probably explains why all three metaevaluations produced very similar findings. 



\section{INTRODUCTION}

\subsection{BACKGROUND}

Under the sponsorship of the U.S. Department of Energy (DOE), the national Weatherization Assistance Program has weatherized about five million low-income residences since its inception in 1976. This federally funded program, which is implemented by state and local agencies in all 50 states and the District of Columbia, is designed to increase residential energy efficiency, thereby lowering energy costs for low income occupants and improving their health and comfort.

This report documents the findings of a recent metaevaluation of the Weatherization Assistance Program conducted by staff at Oak Ridge National Laboratory (ORNL). A metaevaluation is a study that uses as its data points the findings from a number of individual studies on the topic of interest. In this case, the performance of the national Weatherization Assistance Program is the focus, and the data points are the findings from 37 state-level evaluations of weatherization efforts completed between 1993 and 2002. The states whose studies were used in this metaevaluation are shown in Figure 1.

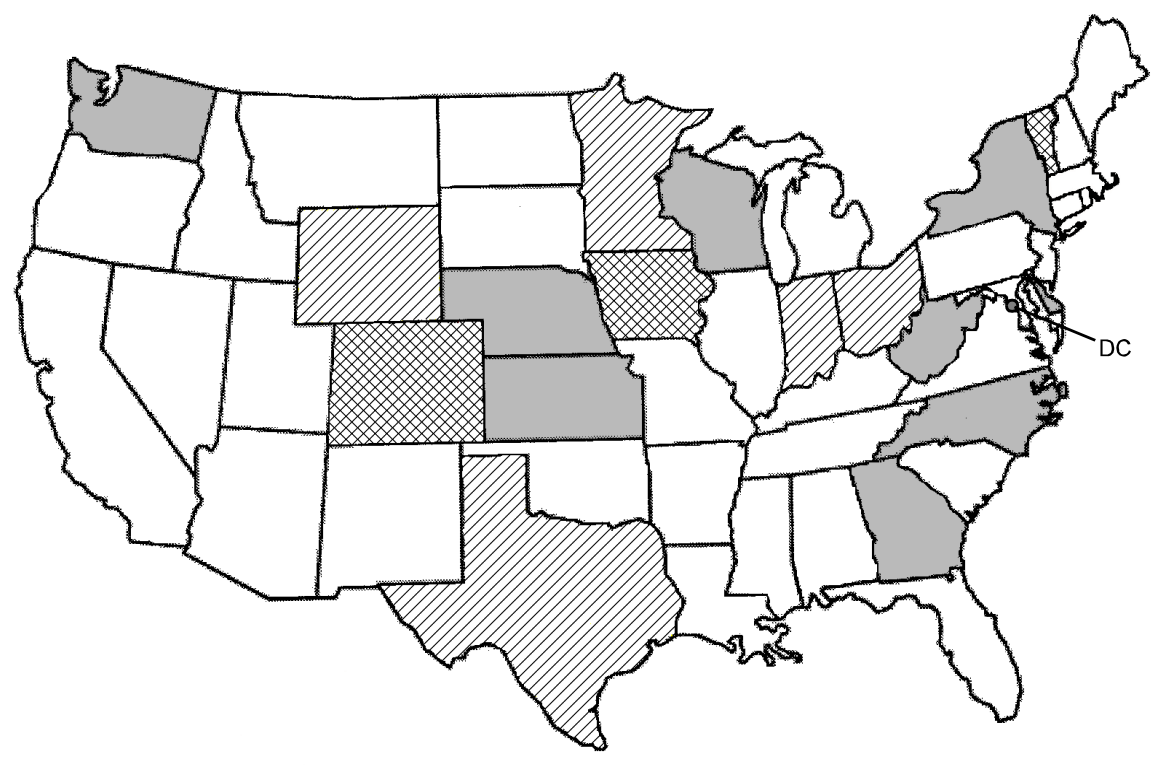

One Study

Two Studies

More than Two Studies

Figure 1. States with studies used in the third metevaluation. 
The current metaevaluation is a follow-up to two earlier metaevaluations of the Weatherization Assistance Program performed by ORNL in 1996 (Berry 1997) and in 1998 (Schweitzer and Berry, 1999). Each of these three metaevaluations was performed in order to update the findings from a national evaluation of the Weatherization Assistance Program that ORNL conducted on the 1989 Program Year in the early 1990s (Brown, Berry, Balzer, and Faby 1993).

Between the completion of the first and second metaevaluations and the beginning of the current, or third, metaevaluation, few dramatic changes were made in that part of the Weatherization Assistance Program that addresses heating energy use. Accordingly, the authors began this project with the expectation that a current national estimate of the amount of natural gas saved in a typical home that heats with natural gas would be similar to what was found in the two previous metaevaluations. This, in fact, proved to be the case.

\subsection{SCOPE OF REPORT}

The subsequent chapters of this report describe the research methods used in this metaevaluation and discuss its key findings. Chapter 2 provides information on the 37 state studies that were examined and explains how the data provided by these individual studies were analyzed. Chapter 3 presents energy and dollar savings results and benefit/cost ratios for a typical Program house that heats with natural gas. Chapter 4 summarizes the study findings.

Findings for homes that heat with electricity, fuel oil or propane are not presented in the main body of this report because the number of states that studied these heating fuels was too small to permit reliable regression modeling for the nation. However, a discussion of fuel oil and propane savings in Minnesota for the 2000-2001 and 2001-2002 heating seasons is presented in Appendix A. Six state-level measurements of electricity savings in homes that heat with electricity are discussed in Appendix B. Measurements of electricity savings for baseload end-uses from two studies in Iowa and two in Vermont are discussed in Appendix C. 


\section{METHODS}

\subsection{LOCATING RECENT STATE-LEVEL EVALUATIONS}

The first step in conducting this metaevaluation was to identify the states that had evaluated their weatherization programs since September of 1998, when the second survey of state evaluations was completed by ORNL. In June and July of 2002, weatherization staff in each state office were contacted to determine which states had completed evaluations of their programs since 1998. We already knew the status of current evaluation efforts in four states that had worked closely with ORNL to design and implement weatherization program evaluations in the past few years. For the other 46 states and the District of Columbia, we elicited the needed information by contacting their weatherization staff to ask for a description of any evaluations that had been completed in their jurisdiction since September of 1998. If state weatherization staff responded that an evaluation had been completed during the past four years, we requested a copy of the report documenting their study.

After identifying ten recent state-level evaluations, with the methods described above, we designed a data collection form to record values for the variables that would be needed to integrate the findings of the various studies. Although we requested information only on those evaluations that had been completed since September 1998, some of the studies that we reviewed covered program years prior to 1998 because of the substantial amount of time required to collect and analyze energy consumption data and to prepare reports documenting study findings.

\subsection{SELECTING THE SET OF STATE-LEVEL EVALUATIONS TO INCLUDE IN THE ANALYSIS OF NATURAL GAS SAVINGS}

Even though the first and second metaevaluations used separate sets of state-level studies of savings in homes that heat with natural gas, there was little difference in their results. Our initial analysis efforts for this report involved repeating the same procedures that had been used in the previous two reports. That is, we began by examining only the state-level evaluations that had become available between 1998 and 2002. Once again, we found little difference in the natural gas savings estimates that were produced with this third set of the most recently available state-level evaluations. This lack of difference in the findings from the three data sets is illustrated by Figure 2, which shows mean energy savings and the $90 \%$ confidence intervals for each data set. Clearly, the $90 \%$ confidence intervals overlap each other very substantially, and each of the means falls within the $90 \%$ confidence intervals of the other two data sets. ${ }^{1}$

\footnotetext{
${ }^{1} \mathrm{~A}$ linear model was used to test for differences in the savings estimates by computing estimates of the differences and standard errors of the estimates. For each pair of metaevaluations, the ratio of the difference estimate to its standard error is a t-statistic for testing the hypothesis of no difference. No significant differences were found with this test. However, because the confidence intervals for these differences are broad, the statistical tests do not establish with certainty that no differences exist.
} 


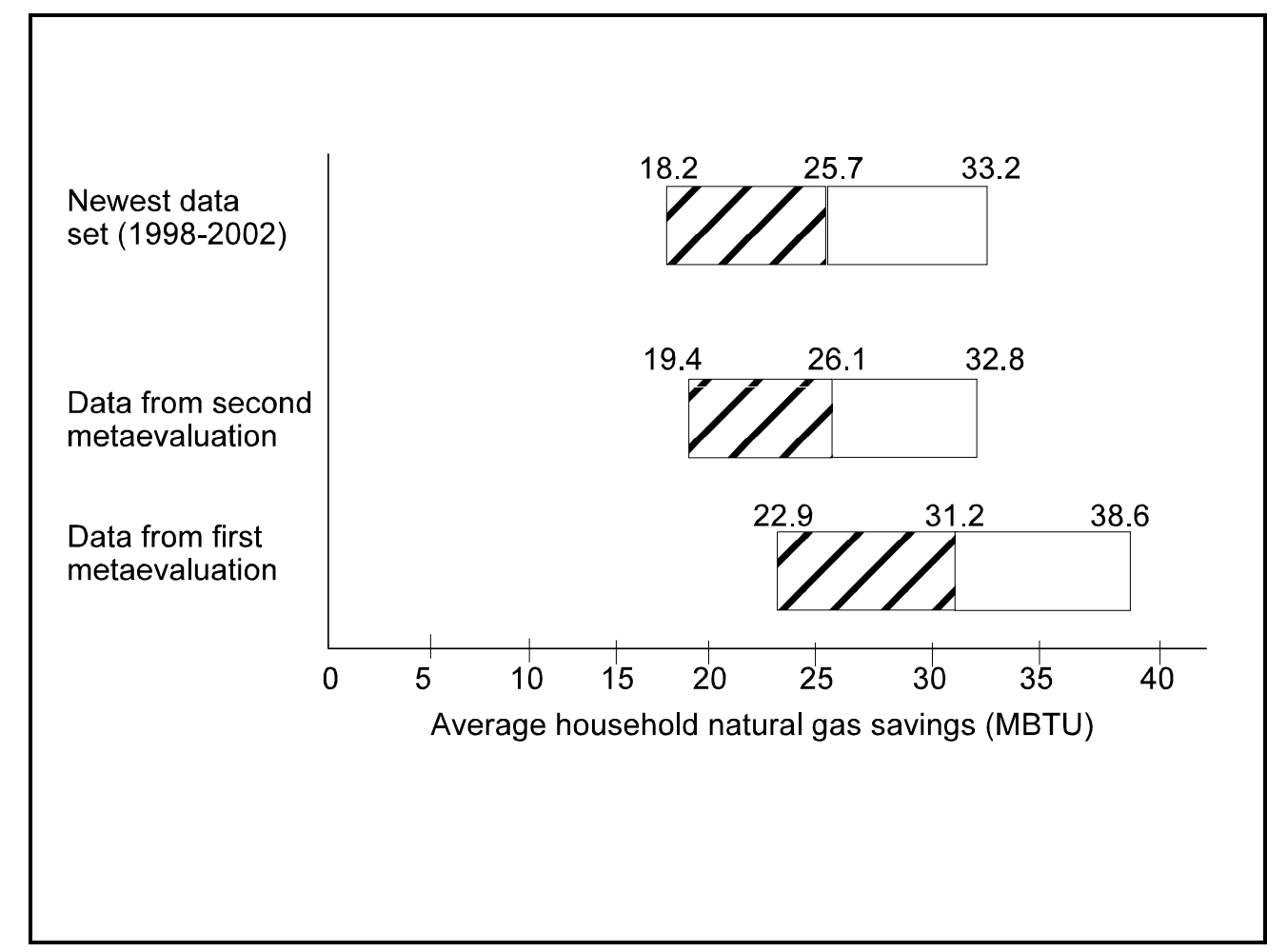

\section{Figure 2. Comparison of whole-house natural gas savings from three data sets: means and $90 \%$ confidence intervals.}

In order to increase our sample size, improve our ability to cover all of the major climate regions in the United States, and add to the statistical rigor of our results, we decided to include findings from all of the post-1992 state-level evaluations of savings in homes that heat with natural gas in our analysis. The number of the information request to State Weatherization offices (1st, 2nd, or 3rd) that first located each state-level evaluation is shown in Table 1. The purpose of this report, like that of the two earlier ORNL metaevaluations, is to provide a current estimate of typical energy savings per weatherized home for the Weatherization Assistance Program based on a set of relevant state-level studies. All three of the metaevaluations, including this one, were designed to be updates to the findings of a national evaluation of the Weatherization Assistance Program that had examined a representative national sample of several thousand structures weatherized in 1989 (Brown, Berry, Balzer, and Faby 1993). Although each of the state-level studies included in our analysis selected samples only from the population of homes weatherized in their own state, when the samples from all of the 28 state-level evaluations are combined they provide information on natural gas savings in more than 10,000 weatherized homes. 
Table 1. Studies used in 2002 metaevaluation

\begin{tabular}{|c|c|c|c|c|}
\hline \multirow[b]{2}{*}{ State } & \multirow[b]{2}{*}{$\begin{array}{l}\text { Information } \\
\text { request to states }\end{array}$} & \multicolumn{3}{|c|}{ Fuel studied* } \\
\hline & & Natural gas & $\begin{array}{c}\text { Electricity } \\
\text { (space-heating) }\end{array}$ & $\begin{array}{c}\text { Electricity } \\
\text { (baseload/no } \\
\text { heating) }\end{array}$ \\
\hline Colorado & $1 \mathrm{st}$ & $X$ & & \\
\hline Colorado & 2nd & $X$ & & \\
\hline Colorado & $3 \mathrm{rd}$ & $X$ & & \\
\hline Delaware & 2nd & & $X$ & \\
\hline District of Columbia & 2nd & $X$ & $X$ & \\
\hline Georgia & $3 \mathrm{rd}$ & $\mathrm{X}$ & & \\
\hline Indiana & $1 \mathrm{st}$ & $\mathrm{X}$ & & \\
\hline Indiana & 2nd & $\mathrm{X}$ & & \\
\hline Iowa & $1 \mathrm{st}$ & $X$ & & \\
\hline Iowa & 2nd & $X$ & & \\
\hline Iowa & $2 \mathrm{nd}$ & $X$ & & $X$ \\
\hline Iowa & $3 \mathrm{rd}$ & $X$ & & $X$ \\
\hline Kansas & $1 \mathrm{st}$ & $X$ & & \\
\hline Minnesota & $1 \mathrm{st}$ & $X$ & & \\
\hline Minnesota & 2nd & $X$ & & \\
\hline Nebraska & $1 \mathrm{st}$ & $\mathrm{X}$ & & \\
\hline New York & $1 \mathrm{st}$ & $\mathrm{X}$ & & \\
\hline North Carolina & $1 \mathrm{st}$ & $X$ & & \\
\hline Ohio & $1 \mathrm{st}$ & $X$ & & \\
\hline Ohio & 2nd & $\mathrm{X}$ & $\mathrm{X}$ & \\
\hline Texas & $3 r d$ & $\mathrm{X}$ & $X$ & \\
\hline Texas & $3 \mathrm{rd}$ & $\mathrm{X}$ & & \\
\hline Vermont & $1 \mathrm{st}$ & $X$ & & \\
\hline Vermont & 2nd & $X$ & & $X$ \\
\hline Vermont & 3 rd & $\mathrm{X}$ & & $\mathrm{X}$ \\
\hline Washington & $3 \mathrm{rd}$ & $X$ & $X$ & \\
\hline West Virginia & $3 \mathrm{rd}$ & & $X$ & \\
\hline Wisconsin & $1 \mathrm{st}$ & $\mathrm{X}$ & & \\
\hline Wyoming & $3 r d$ & $\mathrm{X}$ & & \\
\hline Wyoming & $3 \mathrm{rd}$ & $\mathrm{X}$ & & \\
\hline
\end{tabular}




\subsection{WORKING WITH THE DATA}

The purpose of the data analysis performed in this metaevaluation was twofold: (1) to quantify the energy savings experienced by weatherized households in the states that provided information for this study; and (2) to estimate the average per household savings that could be expected nationwide, based on the findings from our set of state studies.

In this metaevaluation, the average value for any given variable from one study constitutes a single data point. So, for example, the portion of this metaevaluation that examines gas-heated households has 28 data points for pre-weatherization natural gas consumption, with each one consisting of the average consumption calculated from all of the houses examined in one of the state studies. The major outcome of interest in our analysis was the magnitude of natural gas energy savings experienced by the weatherized households. Our data points for this variable are the average annual gas savings identified in each of the state studies of homes that heat with natural gas.

Separate analyses were conducted for different fuel sources and applications:

- The first analysis, the findings of which are presented in Chapter 3, used data from 28 state studies of gas heated houses;

- A second analysis, described in Appendix A, ${ }^{2}$ utilized data gathered by monitoring the performance of fuel oil and propane heating systems in Minnesota;

- A third analysis, discussed in Appendix B, used data from the six state studies of electrically-heated dwellings; and

- The fourth and final analysis, presented in Appendix C, was based on four evaluations of baseload electricity savings in households that did not use electricity for space heating.

\subsection{SAMPLE SIZES AND METHODS OF STATE STUDIES}

The number of houses examined varied widely from study to study. For state-level studies of natural gas consumption, four were based on data for less than 100 houses while another four looked at more than 1,000 houses each. On the electricity side, four of the studies of electrically heated homes examined less than 100 houses and two evaluated savings for more than 1,000 structures. In a few states, studies with different sample sizes from different years were available. Because findings were consistent, regardless of sample size, we did not weight for this variable.

\footnotetext{
${ }^{2}$ The material in Appendix A was prepared mainly by Bruce Tonn and Brad Thompson, with some assistance from Linda Berry
} 
The state-level studies used a variety of methods to measure natural gas savings. In the majority of cases, savings were identified by tracking monthly natural gas bills for a period of approximately 12 months before and 12 months after weatherization. These natural gas billing records were most often analyzed with a software system called PRISM, which stands for PRInceton Scorekeeping Method (Fels, Kissock, Marean, and Reynolds 1995; Fels and Reynolds 1990). In two studies, data loggers were attached to natural gas heating systems to directly measure pre- and post-weatherization heating system run times with the Achieved Savings Assessment Program (ASAP), which uses DESLog software to do weather-normalization and calculate energy savings (Shen et al. 1996; Minnesota Office of Low-income Energy Programs 1998), In the Iowa studies, savings were calculated by applying empirically-derived adjustment factors (developed with PRISM analyses on a subset of all weatherized homes in the state) to engineering estimates of the savings in every weatherized home in the state. The details of the methods used in Iowa are explained in Appendix D. 



\section{FINDINGS}

\subsection{NATURAL GAS SAVINGS FROM STATE STUDIES}

A simple regression analysis based on inputs from 28 state-level evaluations was performed using energy savings as the dependent variable and pre-weatherization consumption as the sole independent variable. Like many previous studies (e.g., Columbia Gas of Ohio 1995; Berry 1997; Schweitzer and Berry 1999), this metaevaluation found a strong positive relationship between pre-weatherization energy consumption and weatherization-induced energy savings $(\mathrm{R}$-Square $=0.671 ; \mathrm{p}=0.0001)$. The R-Square of 0.671 means that $67.1 \%$ of the variance in energy savings is explained by pre-weatherization energy consumption, and the p-value of 0.0001 means that there is a probability of only one in ten thousand that the observed relationship could have occurred by chance. As is shown in Figure 2, the actual observations of savings usually fall close to the prediction line.

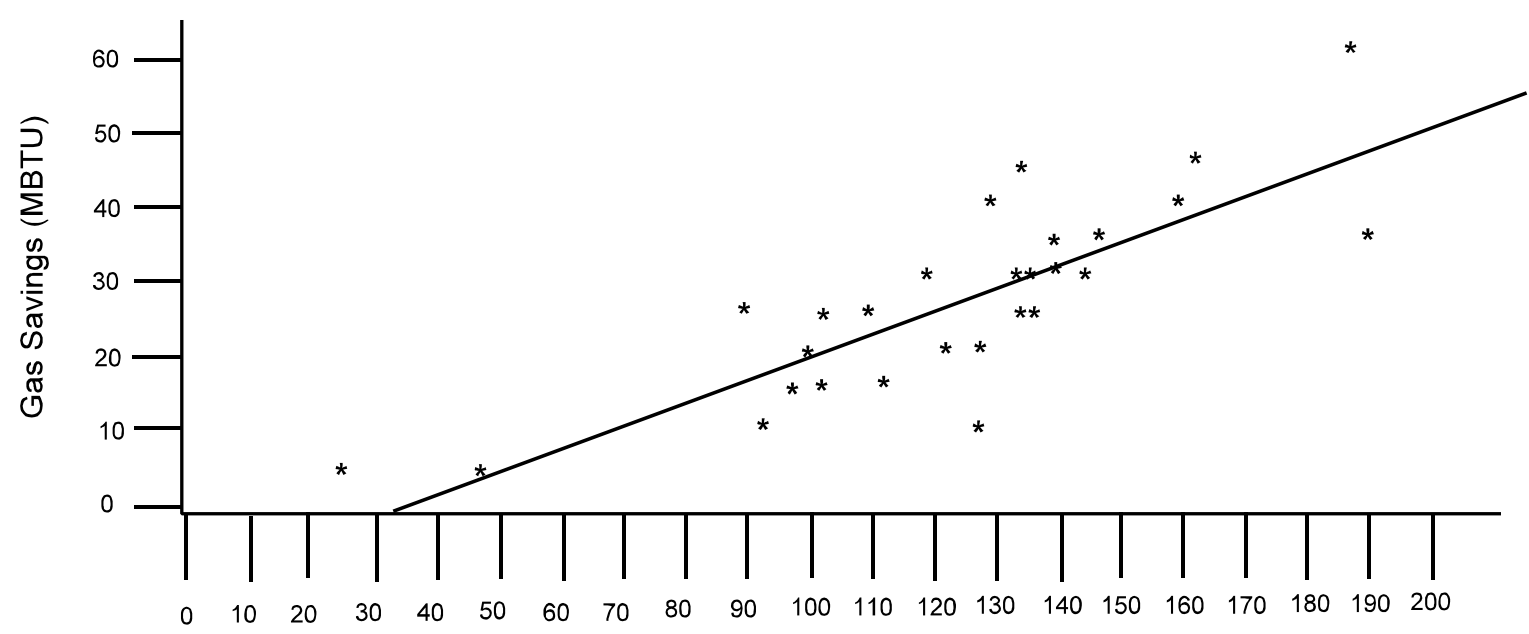

Pre-weatherization whole-house gas consumption (MBTU)

* Actual obserations

Line predicted by regression equation

Figure 3. Plot of actual versus predicted energy savings by pre-weatherization consumption for gas-heated structures. 


\subsection{ESTIMATE OF NATIONAL NATURAL GAS SAVINGS}

As shown in Table 2, the one variable regression model that describes household natural gas savings in terms of its relationship with pre-weatherization energy consumption can be used to predict annual average savings nationwide. This relationship between pre-weatherization consumption and energy savings does not apply only to the 28 states included in the metaevaluations or to studies performed in the last decade. A test metaevaluation was recently performed by the authors using eight state-level studies from the 1980s, several of which described states not covered in the metaevaluations discussed in this report. That analysis found that pre-weatherization energy use accounted for nearly $55 \%$ of the variance in energy savings. And in the national weatherization evaluation, a multi-variable regression analysis revealed that preweatherization energy use accounted for more of the variance in energy savings than any of the 13 other factors examined (Brown, Berry, Balzer and Faby, 1993). Together these studies provide evidence that the relationship between pre-weatherization consumption and energy savings applies to the nation as a whole and is stable over time. Accordingly, employing a single-variable regression model that has pre-weatherization energy consumption as its sole explanatory variable is a good way to estimate national energy savings.

The descriptive equation produced by our simple linear regression analysis showed that natural gas savings equal -11.29 plus the product of pre-weatherization consumption times 0.3035 . By inserting the national average of pre-weatherization household natural gas consumption into this equation, we can estimate average national savings for dwellings that heat with natural gas. According to the national weatherization program evaluation (Brown, Berry, Balzer, and Faby 1993), average pre-weatherization natural gas consumption for all end uses is 133 million BTUs per Program house. Using this input, our estimate of average national savings is 29.1 million BTUs per house per year. This amounts to $21.9 \%$ of average pre-weatherization consumption for all end uses. The $90 \%$ confidence intervals for estimated average household energy savings and for average savings as a percentage of pre-weatherization consumption are included in Table 2 and Table 3.

The average national savings for gas-heated households in 2002 can be compared to the findings from the first two metaevaluations and the national evaluation of the 1989 weatherization program. As shown in Table 3, average savings for gas-heated households as a percent of pre-weatherization consumption for all end uses averaged $21.9 \%$ with the estimation methods used in this report, $19.6 \%$ in the second metaevaluation, $23.4 \%$ in the first metaevaluation, and $13.0 \%$ in the 1989 national evaluation. Although most of the state-level evaluations did not measure the portion of total pre-weatherization consumption used for space heating, this was assumed to be $71 \%$ to allow comparison with previous studies. With this assumption, natural gas savings as a percent of pre-weatherization consumption for space heating averaged $30.8 \%$ in the years covered here, $27.6 \%$ in the second metaevaluation, $33.5 \%$ in the first metaevaluation, and $18.3 \%$ in 1989. 
Table 2. Estimate of average national savings using pre-weatherization consumption as predictive variable

One-variable regression equation $\left[R^{2}=0.671 ; p=.0001\right]$ :

Annual natural gas savings $=-11.29+(0.3035 \times$ pre-weatherization consumption $)$

National average of pre-weatherization household natural gas consumption for all end uses:

133 MBTU* $^{*}$

Predicted average household natural gas savings, nationwide:

$-11.29 \mathrm{MBTU}+(0.3035 \times 133 \mathrm{MBTU})=29.1 \mathrm{MBTU}$

90\% confidence interval: $26.6-31.6 \mathrm{MBTU}(29.1 \pm 2.5)$

Predicted average household savings as a percent of pre-weatherization consumption for all end uses of natural gas:

$29.1 \mathrm{MBTU} / 133 \mathrm{MBTU}=21.9 \%$

90\% confidence interval: $19.9-23.9 \%(21.9 \% \pm 2.0)$

*Weighted national average for Program homes that heat with natural gas taken from 1989 National Weatherization

Evaluation (Brown, Berry, Balzer, and Faby 1993).

Table 3. Estimated national savings for a typical gas-heated home in 2002 and in 1989

\begin{tabular}{lccc}
\hline & $\begin{array}{c}\text { Average household } \\
\text { Average household } \\
\text { natural gas savings, } \\
\text { in MBTU }\end{array}$ & $\begin{array}{c}\text { Average household } \\
\text { a percent of pre- } \\
\text { weatherization } \\
\text { consumption for all } \\
\text { end uses }^{a}\end{array}$ & $\begin{array}{c}\text { Avatural gas savings as } \\
\text { a percent of pre- } \\
\text { weatherization } \\
\text { consumption for } \\
\text { space-heating }\end{array}$ \\
\hline $\begin{array}{l}\text { Current ORNL } \\
\text { metaevaluation }\end{array}$ & 29.1 & 21.9 & 30.8 \\
$\begin{array}{l}\text { Second } \\
\text { metaevaluation }\end{array}$ & $(26.6-31.6)$ & $(19.9-23.9)$ & $(28.1-33.5)$ \\
First metaevaluation & 26.1 & 19.6 & 27.6 \\
$\begin{array}{l}\text { 1989 national } \\
\text { evaluation }\end{array}$ & $(22.9-38.6)$ & $(14.6-24.6)$ & $(20.5-34.7)$ \\
\hline
\end{tabular}

${ }^{a}$ Followed by $90 \%$ confidence interval 
As is shown in both Table 3 and Figure 4, there is no overlap in the 90\% confidence intervals of the 1989 and 2002 estimates. This indicates that it is unlikely the observed difference in the two estimates could have occurred by chance. In contrast, there is very substantial overlap in the $90 \%$ confidence intervals for the first, second, and current metaevaluations, suggesting that there is little difference in their results.

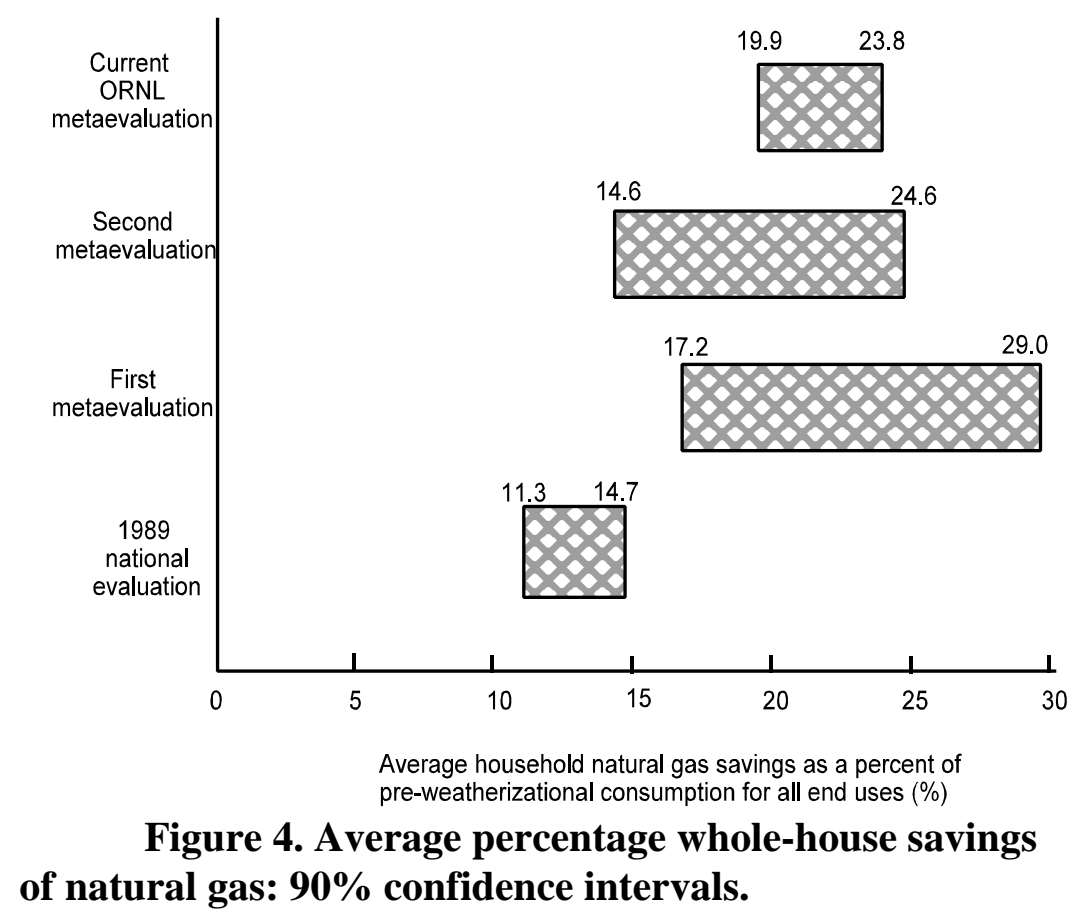

There are several possible reasons why weatherization-induced energy savings for natural gas heating increased between 1989, which was the year studied in the national weatherization evaluation, and the mid-1990's. Between 1992 and 1995 advanced audits became widely used and the use of blower-doors as a diagnostic tool became commonplace. A good description of these changes is offered in a discussion of the reasons for increased savings in the Iowa Weatherization Assistance Program between 1988 and 1995 (Pigg, Dalhoff and Gregory, 1995). As Pigg et al. (1995) point out, the Iowa program emphasized measures such as caulking, weatherstripping and storm windows in the 1980s, but by 1995 the emphasis of the program had shifted to the installation of high density cellulose in wall cavities and to blower-door guided air sealing. In addition, by 1995 measure selection was guided by the National Energy Audit Tool (NEAT), which customizes recommended measure lists to optimize investment returns on a house-by-house basis. 
By 1995, NEAT's customized approach to measure selection had replaced the priority list approach in many states. NEAT and other advanced audits can be expected to produce higher savings than the simple priority list approach that had dominated measure selection procedures in the 1980s. Priority lists assume that the same measure rankings will apply to all houses. The ability of the customized house-by-house measure selection approach of advanced audits to increase average savings by more than $10 \%$ was demonstrated in two experimental field tests conducted in the 1990s (Sharp, 1993; New York State Energy and Research Development Authority and New York Department of State, 1993). The widespread adoption of advanced audits, along with the growing use of blower-door directed air ceiling and high density wall insulation all played a role in the increases in savings that occurred in homes that heat with natural gas between the 1980s and the mid-1990s. There have been no equally dramatic changes in the structure or practices of the Weatherization Assistance Program that address heating energy use in the past few years, which probably explains why all three metaevaluations of state-level evaluations conducted since 1992 produced very similar findings. On the other hand, when the authors recently conducted a test metaevaluation of the state-level evaluations conducted in the 1980s our analysis produced substantially lower estimates of savings (20.4 Mbtu or $15 \%$ of average natural gas consumption) than any of the three metaevaluations that were based on the state-level evaluations conducted in the 1990s.

\subsection{COST EFFECTIVENESS RESULTS FOR BUILDINGS HEATED WITH NATURAL GAS}

Benefit/cost ratios for natural gas were calculated for the weatherization program with the estimated national average annual energy savings of 29.1 million Btu per household. Annual fuel savings in physical units were multiplied by either reported (for 2000, 2001 and part of 2002) or forecasted (for 2003 until 2020) average national gas prices to get average annual dollar savings. The reported average prices and price forecasts were obtained from the Energy Information Administration's website in September of 2002.

Average program costs were estimated by taking the costs reported by the state-level evaluations that measured natural gas savings and weighting each state's total reported costs by the proportion of the total national budget allocated to that state. For example, because Ohio receives over ten times as much funding as Vermont, and about three times as much funding as Iowa or Colorado, its reported costs were weighted more heavily. This weighting procedure increased the estimate of typical costs used in the benefit/cost calculation by about $\$ 161.00$. It seems likely to be a better reflection of a typical investment nationwide than a simple, unweighted average of reported costs.

Two perspectives for estimating cost effectiveness were used: the program perspective, and the societal perspective. The program perspective compares the discounted value of energy savings to total program costs (including labor, materials, 
overhead, administrative and all other categories of fixed or variable costs). The societal perspective compares the discounted value of both energy and non-energy benefits to total program costs.

The assumptions used included an average measure lifetime of 20 years, a discount rate of $3.2 \%$, and a net present value of non-energy benefits of $\$ 3346$, as estimated by Schweitzer and Tonn (2002). ${ }^{3}$

The price forecasts for natural gas were taken from the Energy Information Administration's website in September of 2002. At that time, there was little projected increase in the real price of natural gas over the next 20 years. It is important to keep in mind that natural gas price forecasts were much higher in 2001, when there was a large spike in natural gas prices, than they were in 2002. In addition, natural gas price forecasts are likely to change repeatedly, and somewhat unpredictably, during the 20 -year lifetime of the weatherization measures. Because of the inherent uncertainty in the price forecasts, as well as in a number of other necessary assumptions, there also is unavoidable and significant uncertainty in any estimate of a benefit/cost ratio.

Using the assumptions and price forecasts discussed above, with the program perspective, the calculated benefit/cost ratio was 1.30. This means that an estimated $\$ 1.30$ of lifetime benefits would be received for every $\$ 1$ spent. With the societal perspective, which includes the value of both energy and non-energy benefits, the calculated benefit/cost ratio increased to 2.70. This is consistent with the fact that most efforts to estimate the non-energy benefits of weatherization have reported that they are at least as large as the energy savings benefits (Schweitzer and Tonn 2002; Reed et al. 1997).

\footnotetext{
${ }^{3}$ Schweitzer and Tonn (2002) quantified the value of nonenergy benefits of three types: ratepayer benefits, household benefits and societal benefits. Ratepayer benefits included reductions in bad debt writeoffs, the carrying costs of arrearages, in emergency gas service calls, and in T \& D losses. Benefits to households included fewer fires and illnesses, increased property values, reduced mobility and transaction costs. The societal benefits included reductions in air pollution, increases in employment, and improved national security.
} 


\section{CONCLUSIONS}

Mean values for pre-weatherization natural gas consumption and for weatherization-induced natural gas savings, as reported by 28 state studies of gas-heated residences, were used as inputs for the development of a simple linear regression model. The results of the regression analysis revealed a strong positive relationship between pre-weatherization natural gas consumption and weatherization-induced natural gas savings $(\mathrm{R}-\mathrm{Square}=0.671 ; \mathrm{p}=0.0001)$. This means that, consistent with the findings from many previous studies, households with higher pre-weatherization energy use will typically save more energy when they are weatherized. The R-Square value of 0.671 means that $67.1 \%$ of the variance in natural gas savings is explained by pre-weatherization levels of natural gas consumption.

Using the results of the regression model described above, we estimated average national savings per weatherized household that heats with natural gas. This was accomplished by applying the parameters of the regression equation of the predictive model to the average national value for the independent variable of pre-weatherization natural gas consumption in Program homes. The descriptive equation produced by the simple regression analysis mentioned above had an intercept value of -11.29 and a slope value of 0.3035 . The weighted national average for pre-weatherization consumption in Program homes that heat with natural gas is 133 million BTUs per year. Using these parameters and inputs, the estimate of national average household savings in homes that heat with natural gas is 29.1 million BTUs annually. This represents $21.9 \%$ of average pre-weatherization consumption of natural gas for all end uses and $30.8 \%$ of pre-weatherization space heating consumption..

For electrically-heated houses, savings averaged $10.5 \%$ of pre-weatherization whole-house energy use and $26.7 \%$ of pre-weatherization space heating consumption. This indicates that the Weatherization Assistance Program achieves approximately the same results in both gas- and electrically-heated dwellings in terms of reducing the amount of energy used for space heating.

With average savings of 29.1 million BTUs annually, a benefit/cost ratio was calculated for a typical gas-heated home. Two different perspectives were used: the program perspective, which compares the discounted value of energy savings to total program costs; and the societal perspective, which compares the discounted value of both energy and non-energy benefits to total program costs. The benefit/cost ratio for the program perspective was 1.30 (assuming a discount rate of $3.2 \%$ and the fuel price forecasts shown on the Energy Information Administration's website in September of 2002). The calculated benefit/cost ratio for the societal perspective was 2.70 .

The estimated savings for a typical gas-heated home in 2002 can be compared to the findings from the national evaluation of the 1989 weatherization program. Average savings for gas-heated households as a percent of pre-weatherization consumption for all 
end uses averaged $13.0 \%$ in the 1989 national evaluation. With the estimation methods described in this report, a savings of $21.9 \%$ would be expected today. Although most of the state-level evaluations did not measure the portion of total pre-weatherization consumption used for space heating, this was assumed to be $71 \%$ to allow comparison with previous studies. With this assumption, natural gas savings as a percent of pre-weatherization consumption for space heating averaged $18.3 \%$ in 1989 and $30.8 \%$ in the years covered here. 


\section{REFERENCES}

Berry, Linda, 1997. State-Level Evaluations of the Weatherization Assistance Program in 1990-1996: A Metaevaluation That Estimates National Savings, ORNL/CON-435, Oak Ridge National Laboratory, Oak Ridge, Tennessee, January.

Blasnik, Michael, 1998. Impact Evaluation of Ohio's Home Weatherization Assistance Program, 1994 Program Year, Final Draft \#3, Columbus, Ohio, May 28.

Brown, Marilyn A., Linda Berry, Richard Balzer, and Ellen Faby, 1993. National Impacts of the Weatherization Assistance Program in Single-Family and Small Multifamily Dwellings, ORNL/CON-326, Oak Ridge National Laboratory, Oak Ridge, Tennessee, May.

Columbia Gas of Ohio, 1995. An Administrative Report on the Columbia Gas 1993-94 Warm Choice Program, prepared by A\&C Enercom, Inc., for Columbia Gas of Ohio.

Dalhoff and Associates, 1996. An Evaluation of the 1995 Iowa Low-Income Collaborative Weatherization Program, a report prepared for the Iowa Low-Income Collaborative Weatherization Program by Dalhoff and Associates, Verona, Wisconsin, November 5.

Dalhoff and Associates, 1997. Report on Impacts and Costs of the 1996 Iowa Low-Income Weatherization Program, a report prepared for the Iowa Low-Income Weatherization Program by Dalhoff and Associates, Verona, Wisconsin, May 31.

Dalhoff and Associates, 2001. Report on Costs and Impacts of the 2000 Iowa Low-Income Collaborative Weatherization Program, a report prepared for the Iowa Low-Income Collaborative Weatherization Program by Dalhoff and Associates, Verona, Wisconsin.

Dalhoff and Associates, 2001. An Evaluation of the Impacts of Vermont's Weatherization Assistance Program, a report prepared for the Vermont State Office of Economic Opportunity by Dalhoff and Associates, Verona, Wisconsin.

Fels, Margaret F., and Cathy L. Reynolds, 1990. "Now That I've Run PRISM, What Do I Do with the Results?" Home Energy, September/October, pp. 27-34.

Fels, Margaret F., Kelly Kissock, Michelle A. Marean, and Cathy Reynolds, 1995. PRISM (Advanced Version 1.0) User's Guide, Center for Energy and Environmental Studies, Princeton University, Princeton, New Jersey, January. 
Heim, Richard R. Jr., Cindy Garvin, and Larry Nicodemus, 1993. State, Regional, and National Monthly and Seasonal Heating Degree Days Weighted by Population (1990 Census) July 1931-June 1992, National Oceanic and Atmospheric Administration, Asheville, North Carolina, July.

Hendron, Robert, 1997. Analysis of Energy Savings Achieved by DCEO Weatherization Program, 1997. DOE Philadelphia Regional Support Office, December 31.

Indiana CAP Directors' Association, Inc., 1992. Energy Savings in Homes Weatherized by Six Indiana Weatherization Agencies: An Evaluation of Measured Savings and Cost Effectiveness, prepared by William H. Hill, Center for Energy Research/Education/Service, Ball State University, Muncie, Indiana.

The Statewide Low-Income Collaborative Evaluation (SLICE) of Iowa, 1994. An Evaluation of Iowa's Low-Income Weatherization Efforts, prepared by Wisconsin Energy Conservation Corporation, August 8.

New York State Energy Research and Development Authority and New York Department of State 1993. Instrumented Audits Technology Transfer Project, prepared by Synertech Systems Corporation. Energy Authority Report 94-6.

Minnesota Office of Low-Income Energy Programs, 1998. User's Manual for ASAP, Featuring DESLog.

Public Service Company of Colorado, 1995. Performance Measurement of the Energy Savings Partners Program, prepared by the Program Evaluation Unit of Public Service Company of Colorado.

Pigg, Scott, Greg Dalhoff and Judy Gregory 1995. "Measured Savings from Iowa's Weatherization Program," pp. 163-169 in the Proceedings of the 1995 Energy Program Evaluation Conference, Chicago, Illinois, August.

Reed, John H., Nicholas P. Hall, Andrew Oh, Paul Hoover, and John Oh, 1997. An Impact Evaluation of Vermont's Weatherization Assistance Program, a report prepared for the Vermont State Office of Economic Opportunity by TecMRKTWorks, Arlington Virginia, December.

RLW Analytics, Inc., 1998. Public Service Company of Colorado and Colorado Office of Energy Conservation, Evaluation of the Energy Saving Partners Program Impact Evaluation, DRAFT, Clark Lake, Michigan, April 15.

Schweitzer, Martin and Linda Berry, 1999. Metaevaluation of National Weatherization Assistance Program Based on State Studies 1996-1998, ORNL/CON-467, Oak Ridge National Laboratory, Oak Ridge, Tennessee, May. 
Schweitzer, Martin and Linda Berry, 2001. Evaluation of the Washington State Weatherization Assistance Program, ORNL/CON-478, Oak Ridge National Laboratory, Oak Ridge, Tennessee, March.

Schweitzer, Martin and Bruce Tonn, 2002. Nonenergy Benefits from the Weatherization Assistance Program: A Summary of Findings from the Recent Literature. ORNL/CON-484, Oak Ridge National Laboratory, Oak Ridge, Tennessee, April.

Shaber, Russ , 2002. Energy Use Study for the Energy Savings Partners of Colorado Homes Heated with Natural Gas Provided by Excel Energy, 1998-1999 Program Year: Interim Report.

Sharp, Terry, 1993. The North Carolina Field Test: Field Performance of the Preliminary Version of an Advanced Weatherization Audit for the Department of Energy's Weatherization Assistance Program, ORNL/CON-362, Oak Ridge National Laboratory, Oak Ridge, Tennessee, May.

Shen, Lester S., David L. Bohac, Karen L. Linner, and Timothy S. Dunsworth, 1996. Development of Production-Based Tools and Protocols for Weatherization Program Assessment, Final Report for Minnesota Department of Economic Security, Minneapolis, Minnesota, September 10.

Stiles, Jan, Rana Belshe, and Judith Gregory, 1997. State of Wyoming Weatherization Evaluation: A Focus Tool for Change.

Texas Department of Housing and Community Affairs, 1995. Final Report: Advanced PRISM Analysis of 182 Houses in Texas that Underwent Energy Retrofits, prepared by J. Wang, D. Claridge, J. Haverl, and T. Reddy Energy Systems Laboratory, Texas A\&M University.

Vermont State Office of Economic Opportunity, Weatherization Assistance Program, 1993. Impact Evaluation of the 1992-1993 Vermont Weatherization Assistance Program, prepared by Vermont Energy Investment Corporation.

Vermont State Office of Economic Opportunity, Weatherization Assistance Program, 1995. Impact Evaluation of the 1993-1994 Vermont Weatherization Assistance Program, prepared by Vermont Energy Investment Corporation.

Wang, Young-Doo, Joseph K. Berko, Jr., Kyung-Jin Boo, John Byrne, and Deirdre Rockwell Lord, 1996. Impacts of the Delaware Low-Income Weatherization Program on Energy and Economic Savings, Newark, Delaware, December. 



\section{APPENDIX A}

\section{OTHER FUELS STUDY RESULTS \\ by \\ Bruce Tonn, Brad Thompson, and Linda Berry}

\section{A.1 INTRODUCTION}

Nearly all past evaluations of the Weatherization Assistance Program (the Program) have relied on natural gas billing records that were analyzed with the Princeton Scorekeeping Method (PRISM). Between 1989 and 1996, several state-level evaluations demonstrated a trend toward higher savings in homes that heat with natural gas. The 1996 metaevaluation (Berry, 1997), for example, reported that energy savings, measured with PRISM, for homes that heat with natural gas in Vermont and Ohio had increased significantly between 1989 and 1996. It seemed likely that similar trends toward increased savings over time in homes that heat with fuel oil and propane might be present. This possibility was the motivation for conducting the Other Fuels study, which began in 1999. This study was designed to measure heating savings in homes that heat with fuel oil and propane by monitoring heating system run-times with data loggers that would be installed by local weatherization agencies. The methods of data collection and the results of the Other Fuels study are discussed in this Appendix.

Oak Ridge National Laboratory (ORNL) conducted the Other Fuels Study in collaboration with Weatherization Program staff members in the states of Minnesota and Michigan. The major goal of the study was to obtain an updated estimate of savings in homes that heat with fuel oil and propane. Several local agencies in Minnesota and one local agency in Michigan installed monitoring equipment on the heating systems of homes that they weatherized during the heating seasons of 2000-2001 and 2001-2002. Seventy-five percent of the monitored homes were heated with fuel oil and the rest with propane. The State offices in Minnesota and Michigan collected heating system run-time data files from several local agencies and forwarded them to ORNL, which performed the analysis.

The initial comparison point for the results of the Other Fuels Study comes from an earlier ORNL study of savings in houses that heat with fuel oil (Levins and Ternes, 1994), which was part of the National Evaluation. Levins and Ternes (1994) examined savings in 222 homes weatherized by the Program in the 1991 and 1992 Program years. The homes they studied consisted of a representative sample of weatherized homes drawn from nine northeastern states where fuel oil is a common heating fuel. A comparable control group of 115 houses also was part of their study. Using run-time dataloggers and a regression technique to normalize to standard weather conditions, Levins and Ternes (1994) found an average annual fuel oil savings of $17.7 \%$ of pre-weatherization fuel oil consumption. The $90 \%$ confidence interval for the estimated fuel oil savings ranged from $14.3 \%$ to $21.1 \%$ of pre-weatherization consumption. 


\section{A.2 RESULTS}

The Other Fuels Study, which examined fuel-oil and propane heated homes weatherized in a split-winter research design during the 2000-2001 and 2001-2002 heating seasons in the states of Minnesota and Michigan, showed average heating savings of $21.3 \%$ with a $90 \%$ confidence interval of $15 \%$ to $27.7 \%$. This is only a small increase, which is not statistically significant, over the savings measured for the heating seasons of 1990-1991 and 1991-1992 by Levins and Ternes (1994).

The percentage savings of the Other Fuels Study, which is $21.3 \%$ of the pre-weatherization heating fuel consumption, also is very similar to the percentage of savings that was measured in several post-1995 state level evaluations of savings in homes in cold climates that heat with natural gas. In practical terms, the results of the Other Fuels study indicate that houses that heat with fuel-oil and propane can be expected to have about the same percentage of savings as homes that heat with natural gas. Earlier studies of savings in natural-gas heated homes in Minnesota confirm this conclusion (Shen et al., 1996).

\section{A.3 METHODS}

The Other Fuels study used a metering and software package, which was developed by the Minnesota State Office of the Weatherization Assistance Program in 1995 and 1996. This metering and software package, which is called the Achieved Savings Assessment Program (ASAP), was developed as a tool for on-going program evaluation and quality assurance purposes by the State of Minnesota. ORNL's collaboration with the state of Minnesota was designed not only to obtain an up-to-date measurement of savings in houses that heat with fuel oil and propane, but also to test the implementation of ASAP in a few states and to determine its suitability for more widespread use within the Program network.

\section{A.4 OVERVIEW OF ASAP AND DESLog}

ASAP monitoring begins with the installation of Pacific Science and Technology's run-time SmartLogger CT Loggers on the electric controls of the heating system of each study home. The SmartLogger CT Logger is a portable electronic device that records when a heating system is on (i.e., its run-time) or off. The accompanying software (SmartWare), also from Pacific Science and Technology, is used to download the date and time stamps of the 15-minute run-time values from the loggers.

The downloaded run-time information described above is the first of three required inputs for a software analysis package called DESLog. DESLog, which is a 
Microsoft Excel based spreadsheet program, was developed for the Weatherization Program of Minnesota's Department of Economic Security (DES) in 1995 and 1996. The other required inputs to DESLog are the firing rate of each heating system, and two types of weather data. Weather data are required for both the average daily temperatures for the days included in the study period and the long-term average (12 to 30 year averages) daily temperatures for a normal year of weather.

Reliable model results with ASAP/DESLog were obtained for 45 homes out of the 79 monitored homes for which the local agencies sent enough information to make it possible to run a model. Although some type of information was received for 140 homes where installations of run-time loggers had been attempted, less than $60 \%$ of them $(n=79)$ had complete enough data and records to make analysis of energy savings possible. These losses of nearly half the sample were due largely to poor implementation and record keeping at the local agency level. Some common errors included the following:

- The run-time loggers were reset when they should not have been.

- The run-time loggers were not installed before the house was weatherized.

- Many of the tracking sheets were incomplete and did not include crucial information such as the dates of weatherization and the addresses. Without the addresses it was impossible to identify the correct weather station or, as a result, to analyze savings.

In addition to the failure of the local agencies to implement the ASAP/DESLog monitoring system correctly, a warm winter during the first year of monitoring in Minnesota made it difficult to obtain reliable linear models of the relationship between fuel use and outdoor temperature that could be used to normalize for weather in over $50 \%$ of the 79 homes with complete information.

\section{A.5 SERIOUS FLAWS IN ASAP/DESLOg MAKE ITS USE TOO DIFFICULT}

During the process of using DESLog to analyze the data, ORNL project staff discovered that the software package does not include the ability to produce long-term weather files, even though they are a required analysis input. This step must be done separately and externally. To make things even more difficult, there was no documentation available about how to format or how to produce the required long-term weather files. It was very challenging for us to have to guess how to produce the necessary long-term weather input files and to get them into the model through a trial-and-error process. We eventually were able to solve this problem through consultations with the software's developers. However, resolving this problem would be too difficult for an average user. Furthermore, there is no mechanism in place to provide any technical support to users. Therefore, we cannot recommend that other states attempt to use this monitoring system unless a new technical support mechanism is put into place. 
Another reason that we cannot recommend the more widespread use of ASAP/DESLog is that our experience with even well-trained local agencies was disappointing. Initially, the Other Fuels study included efforts to monitor homes in the four states of Wisconsin, North Dakota, Michigan and Minnesota. Although individuals from the participating local agencies in each of these states received a full day of training from the Minnesota person who had led the effort to develop ASAP/DESLog, only a few local agencies in Minnesota and only one in Michigan successfully delivered usable run-time data files to ORNL. Most of the local agencies that attempted to collect data failed to provide any usable files at all. Out of the 140 homes that had monitoring equipment installed on their heating systems during the heating seasons of either 2000-2001 or 2001-2002, the local agencies provided enough data to allow for an analysis of savings in only 79 homes. Then, out of these 79 homes with complete records available, only 45 had reliable linear models that could be used to normalize for weather.

Although the ASAP/DESLog measurement technique is conceptually sound, and has all of the correct statistical underpinnings, it appears to be too challenging for most local agencies to use even when fairly extensive initial training is provided. Ongoing training and quality control are required for successful implementation. Because the person who once provided training to users is no longer available to provide this service, it seems unlikely that these challenges can be overcome. ASAP/DESLog is not currently recommended for widespread implementation by either state or local level Weatherization Assistance Programs for two related reasons. First, no mechanism for training and technical support is in place at present, and, second, successful implementation will require a high level of ongoing technical support.

\section{A.6 REFERENCES}

Shen, Lester, David Bohac, Karen Linner, and Timothy Dunsworth, 1996. Development of Production-Based Tools and Protocols for the Weatherization Program Assessment: Final Report for Minnesota Department of Economic Security, Minneapolis, Minnesota.

Levins, William and Mark Ternes, 1994. Impacts of the Weatherization Assistance Program in Fuel-Oil Heated Houses, ORNL/CON-327, Oak Ridge National Laboratory, Oak Ridge, Tennessee. 


\section{APPENDIX B}

\section{ELECTRICALLY-HEATED HOUSES}

Six of the studies included in this metaevaluation reported energy savings for electrically-heated houses. Those studies contain data on pre-weatherization energy consumption and subsequent savings for Delaware, the District of Columbia, Ohio, Texas, Washington State, and West Virginia. Table B.1 summarizes the key findings from those studies.

Table B.1. Key findings from six state Weatherization Program studies of electrically-heated houses

\begin{tabular}{|c|c|c|c|c|}
\hline & Minimum & Maximum & Mean & $\begin{array}{c}90 \% \\
\text { Confidence } \\
\text { Interval }\end{array}$ \\
\hline $\begin{array}{l}\text { Pre-weatherization whole- } \\
\text { house consumption }(\mathrm{kWh})\end{array}$ & 11,583 & 25,535 & 19,919 & $15,973-23,864$ \\
\hline $\begin{array}{l}\text { Pre-weatherization heating } \\
\text { consumption }(\mathrm{kWh})^{*}\end{array}$ & 3,938 & 11,734 & 8,183 & $5,627-10,739$ \\
\hline Absolute savings** $(\mathrm{kWh})$ & 1,233 & 3,511 & 2,153 & $1,406-2,899$ \\
\hline $\begin{array}{l}\text { Savings as a percent of pre- } \\
\text { weatherization whole-house } \\
\text { consumption }(\%)\end{array}$ & 6.3 & 13.8 & 10.5 & $8.0-12.9$ \\
\hline $\begin{array}{l}\text { Savings as a percent of pre- } \\
\text { weatherization heating } \\
\text { consumption }(\%)\end{array}$ & 15.3 & 40.4 & 26.7 & $18.0-35.5$ \\
\hline
\end{tabular}

*In those cases where a study did not report pre-weatherization heating consumption, this was calculated from whole-house consumption using the finding reported in ORNL's national Weatherization evaluation (1993) that electrically-heated low-income households nationwide used approximately $34 \%$ of their total household electricity for space-heating purposes.

**Absolute savings is the equivalent of net savings in those cases where a control group was used and gross savings in all other cases. 
As shown above, the simple, unweighted average of pre-weatherization whole-house energy consumption for all six states was 19,919 kilowatt hours (kWh). Of that, an average of $8,183 \mathrm{kWh}$ was used for space heating. The large majority of total electricity consumption was associated with a variety of other household uses (e.g., lighting, home cooling, refrigeration, cooking, clothes washing).

Energy savings reported by the six studies averaged $2,153 \mathrm{kWh}$. This savings number represents 10.5 percent of whole-house pre-weatherization energy consumption. However, average program savings represent a much larger portion (26.7 percent) of the energy used for space heating. The substantial difference in those two numbers is due to the fact that household electricity is used for a myriad of purposes other than heating the dwelling, while the majority of Weatherization measures are traditionally aimed at reducing the amount of energy used for space heating.

Table B. 2 shows how the savings achieved in electrically-heated houses compare to those in dwellings heated by natural gas. In gas-heated houses, average Weatherization-induced savings amounted to 21.9 percent of pre-weatherization whole-house energy consumption, which is about twice the whole-house savings rate achieved in electrically-heated dwellings. However, when Weatherization savings are calculated as a percent of pre-weatherization energy used for space-heating, the results are very comparable. In that case, mean savings are 26.7 percent of space-heating usage for electrically-heated houses, which is nearly equal to the national average of 30.8 percent savings achieved in space heating usage in houses heated with natural gas. This indicates that the Weatherization Assistance Program achieves approximately the same results in both gas and electric homes in terms of reducing the amount of energy required for space heating. However, because electricity is used for so many more household purposes than is natural gas, savings as a percentage of whole-house energy use tend to be substantially lower in electrically-heated dwellings.

Table B.2. Comparison of average savings by electrically- and natural gas-heated houses

Average savings by electrically-heated houses*
Average savings by natural gas-heated houses $^{* *}$

Savings as a percent of pre-

weatherization whole-house

consumption $(\%)$

10.5

Savings as a percent of preweatherization heating consumption (\%) 26.7

*For electrically-heated houses, the average savings numbers shown here are the simple, unweighted means of reported savings for the six states with electricity data.

**For natural gas-heated houses, the average savings numbers shown here represent average national savings as predicted by a regression model based on pre-weatherization energy consumption and energy savings for all 28 states with natural gas data. 


\section{APPENDIX C}

\section{SAVINGS IN HOUSES USING ELECTRICITY ONLY FOR NONHEATING PURPOSES}

The most recent study of electricity savings in Vermont (Dalhoff and Associates, 2001), which relied on a PRISM analysis of electric billing records, found that electricity usage among weatherized homes that did not heat with electricity actually increased between the pre- and post-weatherization years. However, because electric consumption in a control group of homes that did not heat with electricity increased even more during the same time period, the authors estimated net savings at $131 \mathrm{kWh}$ per year. The $90 \%$ confidence interval for this estimate of net electricity savings includes zero. Therefore, to show statistically significant savings one would have to accept a confidence interval of less than 90\%. An earlier study in Vermont (Reed et al. 1997) estimated electricity savings at $280 \mathrm{kWh}$ per year in homes that did not heat with electricity. In this study too, the estimated savings were not significant unless one accepts a confidence interval of less than $90 \%$. The average home in Vermont that does not heat with electricity used about $9,000 \mathrm{kWh}$ per year in both study years. Therefore, average electricity savings as a percentage of pre-weatherization use were less than $4 \%$.

The most recent Iowa evaluation (Dalhoff and Associates, 2001) estimated the electricity savings realized from the installation of high-efficiency replacement lighting measures (including compact fluorescent and capsylite bulbs of various wattages) at $220 \mathrm{kWh}$ per year for the average weatherized home. ${ }^{4}$ This estimate is derived from a combination of engineering estimates and adjustment factors developed from billing records. An earlier study in Iowa (Dalhoff and Associates, 1997), reported savings from lighting retrofits of $240 \mathrm{kWh}$ per year in the average home.

Table C.1. Electricity savings in four state weatherization program studies of non-heating electricity use

\begin{tabular}{lcccc}
\hline & $\begin{array}{c}\text { Vermont } \\
1997\end{array}$ & $\begin{array}{c}\text { Vermont } \\
2001\end{array}$ & $\begin{array}{c}\text { Iowa } \\
1997\end{array}$ & $\begin{array}{c}\text { Iowa } \\
2001\end{array}$ \\
\hline $\begin{array}{l}\text { Net electricity savings in homes that } \\
\text { do not heat with electricity (kWh) }\end{array}$ & 280 & 131 & 240 & 220 \\
\end{tabular}

${ }^{4}$ This study also reported engineering estimates of electricity savings for reductions in the use of furnace fans (448 kWh/year) in homes that received building shell measures and in the use of water heaters (511 kWh/year) for homes that received water heating measures. Both of these estimates include a few homes that also use electricity for space heating. Therefore, they can not be compared directly to the Vermont study results which did not include homes that heat with electricity. The methods used in the Iowa studies are described in Appendix D. 



\section{APPENDIX D}

\section{EVALUATION METHOD USED IN IOWA STUDIES}

The evaluation methods used for the Statewide Low-income Collaborative Evaluation (SLICE) Committee in Iowa are of particular interest because they use a unique and highly detailed analysis system. From July of 1992 to the present, Iowa's investor-owned gas and electric utilities have implemented energy efficiency programs for their low-income customers in collaboration with Iowa's Weatherization Assistance Program (WAP). The utilities add to the available WAP funding for insulation and infiltration reduction measures and also support the installation of higher efficiency water heating and lighting measures. In recent years, some utilities have expanded funding to include partial contributions to high-efficiency furnace replacements and refrigeration measures.

In 1992, SLICE began sponsoring on-going evaluations of their low-income energy-efficiency programs. The initial SLICE evaluation effort included the development of engineering algorithms that predicted measure-specific savings for all of the measure types installed by the program. The first step in developing these algorithms involved running a building simulation model on approximately 500 households (Energy Economics of Design Options (EEDO) version 2.0 energy audit software was used). Detailed on-site information on each of the 500 households was needed as input to the EEDO software. However, in order to make it possible to estimate house-level savings with less detailed inputs the detailed results were characterized and linked to the less detailed information that was routinely collected by the program. For measures that EEDO did not address (lighting, for example) the analysts developed their own algorithms for calculating engineering estimates of savings. The first analysis of the predicted energy impacts of the program, which was based on this initial set of engineering estimates, was published in 1992 by the Wisconsin Energy Conservation Corporation (WECC).

The second part of the evaluation effort, which was published by WECC in 1994, was prepared after a full year of post-weatherization natural gas consumption data became available. This second analysis compared the predicted savings based on the engineering estimates of the first report to the observed changes in fuel consumption. Using a regression technique, which is often called a Statistically Adjusted Engineering (SAE) model, the analysts calculated adjustment factors that would reconcile the predicted savings with the observed changes in fuel consumption. The coefficients of the SAE model provided the information needed to determine the realization rates (i.e., the relationship between the predicted and observed energy savings) for individual conservation measures. 
The outputs of the SAE model were used to produce adjustment factors that were then applied to estimates of savings that were calculated using the algorithms developed the previous year. This method of reconciling the predicted and observed savings produced an improved set of measure-specific estimates of savings that incorporated the new information on observed energy savings by measure type.

Another round of SAE adjustments was applied to the engineering estimates of savings for the measures installed during the 1994 calendar year. After 1994, Dalhoff and Associates, whose personnel had been part of the team that developed the initial engineering algorithms at WECC, continued using the SAE-adjusted algorithms to estimate savings. From 1999 to the present, the results from the improved set of SAE models have been used to generate measure-specific estimates of savings that are adjusted annually with information taken from natural gas billing records. These annual adjustments are based on total realization rates that are calculated by comparing the total predicted natural gas savings to the total observed savings. For example, if the total realization rate in 1999 were 0.95 , then each measure-specific estimate of natural gas savings (whether for insulation or air infiltration measures) for that year would be multiplied by an adjustment factor of 0.95 . Average total realization rates are calculated by local weatherization agency and by utility to produce annual agency-specific and utility-specific estimates of savings. The utility companies are required to provide this detailed level of information on realized energy savings as part of their cost recovery process. 
ORNL/CON-488

\section{INTERNAL DISTRIBUTION}

1. L. G. Berry

2. M. A. Brown

3. W. G. Craddick

4. T. R. Curlee

5-155. M. T. Eady

156. J. F. Eisenberg

157. E. C. Fox
158. S. G. Hildebrand

159. M. Schweitzer

160. R. B. Shelton

161. B. E. Tonn

162. ORNL Central Research Library

163. ORNL Laboratory Records-RC

\section{EXTERNAL DISTRIBUTION}

164. Mr. Kevin Abott, Community Action Agency of Northeast Alabama, P.O. Box 1487, Rainsville, AL 35986.

165. Mr. Robert Adams, National Association for State Community Service Programs, 400 N. Capitol Street, NW, Suite 395, Washington, DC 20001.

166. Mr. Eric Beaton, U.S. DOE Boston Regional Office, Weatherization Program Manager, JFK Federal Building, Room 675, Boston, MA 02203-0002.

167. Ms. Beth M. Cahall, U.S. DOE Philadelphia Regional Office, Weatherization Program Manager, 1880 John F. Kennedy Boulevard, Suite 501, Philadelphia, PA 19103-7483.

168. Mr. James Childs, U.S. DOE, EE-42, Room: 5E-066, Office of Technology Assistance, 1000 Independence Avenue, SW, Washington, DC 20585.

169. Mr. Rob DeSoto, U.S. DOE Golden Regional Office, Weatherization Program Manager, 1617 Cole Boulevard, Golden, CO 80401.

170. Ms. Jean M. Diggs, U.S. DOE, EE-42, Room: 5E-080, Office of Technology Assistance, 1000 Independence Avenue, SW, Washington, DC 20585.

171. Mt. Jerome Dion, U.S. DOE, EE-40, Room 5E-052, 1000 Independence Avenue, SW, Washington, DC 20585.

172. Mr. Denis J. Feck, U.S. DOE, EE-42, Room: 5E-098, Office of Technology Assistance, 1000 Independence Avenue, SW, Washington, DC 20585.

173. Ms. Carole Gates, U.S. DOE Seattle Regional Office, Weatherization Program Manager, 800 Fifth Avenue, Suite 3950, Seattle, WA 98104.

174. Mr. John Howat, National Consumer Law Center, 77 Summer Street, 10th Floor, Boston, MA 02110-1006.

175-185. Ms. Gail N. McKinley, U.S. DOE, EE-42, Room: 5E-080, Office of Technology Assistance, 1000 Independence Avenue, SW, Washington, DC 20585.

186. Mr. Jerrold Oppenheim, 57 Middle Street, Gloucester, MA 01930.

187. Mr. Michael Peterson, U.S. DOE Chicago Regional Office, Weatherization Program Manager, One South Wacker Drive, Suite 2380, Chicago, IL 60606. 
188. Dr. Meg Power, Economic Opportunity Studies, 444 N. Capitol Street, Suite G-80, Washington, DC 20001.

189. Mr. Gregory M. Reamy, U.S. DOE, EE-42, Room: 5E-066, Office of Technology Assistance, 1000 Independence Avenue, SW, Washington, DC 20585.

190. Mr. Jeff Riggert, TecMRKT Works, 165 W. Netherwood, Oregon, WI 53575.

191. Mr. P. Richard Rittelmann, FAIA, Executive Vice President, Burt Hill Kosar Associates, 400 Morgan Center, Butler, PA 16001-5977.

192. Ms. Bernadette Ruffin, U.S. DOE Atlanta Regional Office, Weatherization Program Manager, 730 Peachtree Street, NE, Suite 876, Atlanta, GA 30308.

193. Dr. Lisa A. Skumatz, Skumatz Economic Research Associates, Inc., 762 Eldorado Drive, Superior, CO 80027.

194. Mr. David Terry, NASEO, 1414 Prince Street, Suite 200, Alexandria, VA 22314.

195. Dr. Susan F. Tierney, The Economic Resource Group, Inc., One Mifflin Place, Cambridge, MA 02138. 